\title{
Metabolism of sucrose and its five isomers by Fusobacterium mortiferum
}

\author{
Andreas Pikis, ${ }^{1,2}$ Stefan Immel, ${ }^{3}$ Stanley A. Robrish ${ }^{1}$ and John Thompson ${ }^{1}$
}

\footnotetext{
1 Microbial Biochemistry and Genetics Unit, Oral Infection and Immunity Branch, National Institute of Dental and Craniofacial Research, National Institutes of Health, Bethesda, MD 20892-4350, USA

2 Department of Infectious Diseases, Children's National Medical Center, Washington DC 200102970, USA

3 Institut für Organische Chemie, Technische Universität Darmstadt, D-64287 Darmstadt, Germany
}

\author{
Author for correspondence: John Thompson. Tel: +1 301496 4083. Fax: +1 3014020396. \\ e-mail: jthompson@dir.nidcr.nih.gov
}

\begin{abstract}
Fusobacterium mortiferum utilizes sucrose [glucose-fructose in $\alpha(1 \rightarrow 2)$ linkage] and its five isomeric $\alpha$-D-glucosyl-D-fructoses as energy sources for growth. Sucrose-grown cells are induced for both sucrose-6-phosphate hydrolase (S6PH) and fructokinase (FK), but the two enzymes are not expressed above constitutive levels during growth on the isomeric compounds. Extracts of cells grown previously on the sucrose isomers trehalulose $\alpha(1 \rightarrow 1)$, turanose $\alpha(1 \rightarrow 3)$, maltulose $\alpha(1 \rightarrow 4)$, leucrose $\alpha(1 \rightarrow 5)$ and palatinose $\alpha(1 \rightarrow 6)$ contained high levels of an NAD ${ }^{+}$plus metal-dependent phospho- $\alpha$-glucosidase (MalH). The latter enzyme was not induced during growth on sucrose. MalH catalysed the hydrolysis of the $6^{\prime}$-phosphorylated derivatives of the five isomers to yield glucose 6-phosphate and fructose, but sucrose 6-phosphate itself was not a substrate. Unexpectedly, MalH hydrolysed both $\alpha$ - and $\beta$-linked stereomers of the chromogenic analogue p-nitrophenyl glucoside 6-phosphate. The gene malH is adjacent to malB and malR, which encode an EII(CB) component of the phosphoeno/pyruvate-dependent sugar:phosphotransferase system and a putative regulatory protein, respectively. The authors suggest that for $F$. mortiferum, the products of malB and malH catalyse the phosphorylative translocation and intracellular hydrolysis of the five isomers of sucrose and of related $\alpha$-linked glucosides. Genes homologous to malB and malH are present in both Klebsiella pneumoniae and the enterohaemorrhagic strain Escherichia coli $0157: H 7$. Both these organisms grew well on sucrose, but only $K$. pneumoniae exhibited growth on the isomeric compounds.
\end{abstract}

Keywords: phospho- $\alpha$-glucosidase, sucrose isomers, sucrose-6-phosphate hydrolase, Klebsiella pneumoniae, Escherichia coli $\mathrm{O} 157: \mathrm{H} 7$

\section{INTRODUCTION}

Many bacterial species, including Klebsiella pneumoniae (Sprenger \& Lengeler, 1988; Titgemeyer et al., 1996), Bacillus subtilis (Fouet et al., 1987), Lactococcus lactis (Thompson \& Chassy, 1981; Thompson et al., 1991; Rauch \& deVos, 1992), Fusobacterium mortiferum (Thompson et al., 1992), Escherichia coli (Schmid et al., 1988) and Clostridium beijerinckii (Tangney et al., 1998; Reid et al., 1999) translocate sucrose simultaneously

Abbreviations: FK, fructokinase; G6P, glucose 6-phosphate; G6PDH glucose-6-phosphate dehydrogenase; HK, hexokinase; 4-MU- $\alpha-G 6 P, 4$ methylumbelliferyl $\alpha$-D-glucopyranoside-6-phosphate; PEP:PTS, phosphoeno/pyruvate-dependent sucrose:phosphotransferase system; pNP- $\alpha$ G6P, $\quad p$-nitrophenyl $\alpha$-D-glucopyranoside 6-phosphate; pNP- $\beta$-G6P, $p$-nitrophenyl $\beta$-D-glucopyranoside 6-phosphate; S6PH, sucrose-6phosphate hydrolase. with phosphorylation at C-6 of the glucosyl moiety via the phosphoenolpyruvate-dependent sucrose: phosphotransferase system (PEP:PTS) (Meadow et al., 1990; Postma et al., 1993). Sucrose 6-phosphate is hydrolysed intracellularly by sucrose-6-phosphate hydrolase $(\mathrm{S} 6 \mathrm{PH})$ to yield glucose 6-phosphate and fructose, which are further metabolized via the glycolytic pathway. The multi-component sucrose-PEP:PTS and S6PH are also expressed by oral streptococci, including Streptococcus mutans (St Martin \& Wittenberger, 1979; Slee \& Tanzer, 1979) and Streptococcus sobrinus (Chen \& LeBlanc; 1992) and dietary sucrose is fermented primarily to lactic acid. By its demineralizing action upon tooth enamel, this organic acid initiates or contributes to the aetiology of dental caries (Loesche, 1986; Van Houte, 1994).

The linkage between the two component sugars of sucrose, i.e. D-glucose and D-fructose, can be modified to 


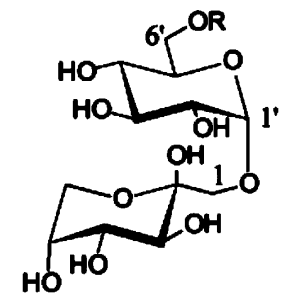

$\beta$-p-Trehalulose $\quad(R=H)$
$\beta-p-T r e h a l u l o s e-6$ P $(R=P)$
$\alpha$-D-Glcp- $(1 \rightarrow 1)-\beta$-D-Frup
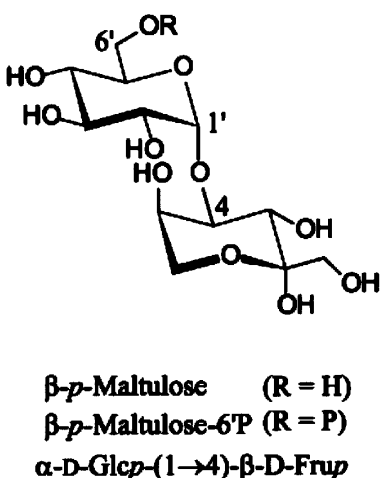

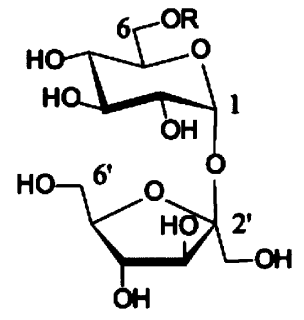

Sucrose $\quad(\mathbf{R}=\mathbf{H})$

Sucrose-6P $(\mathbf{R}=\mathbf{P})$

$\beta$-D-Fruf- $(2 \leftrightarrow 1)-\alpha-D-G l u p$
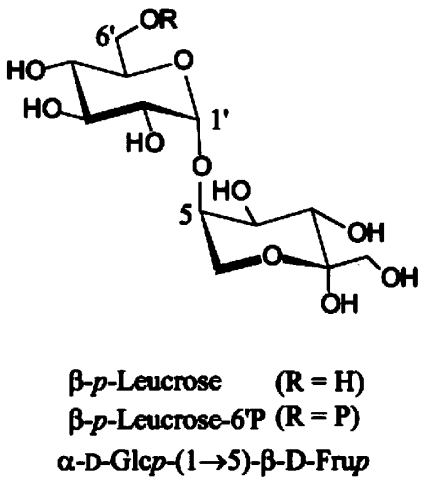

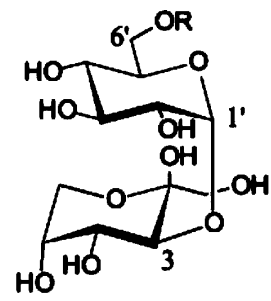

$\beta$-p-Turanose $\quad(\mathrm{R}=\mathrm{H})$

$\beta$-p-Turanose-6'P $(R=P)$

$\alpha-D-G l c p-(1 \rightarrow 3)-\beta-D-F r u p$

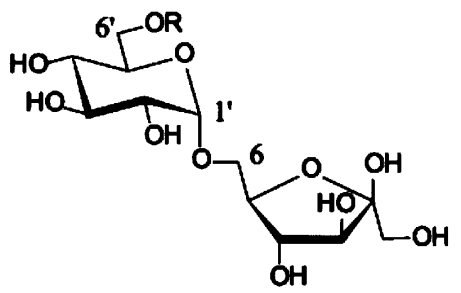

$\beta$-f-Palatinose $\quad(\mathrm{R}=\mathrm{H})$
$\beta-f$-Palatinose-6P $(\mathrm{R}=\mathrm{P})$
$\alpha-D-$ Glcp-(1 $\rightarrow 6)-\beta-\mathrm{D}-\mathrm{Fruf} f$

Fig. 1. Molecular formulae of sucrose and its five isomeric $\alpha$-D-glucosyl-D-fructoses, in both free and phosphorylated forms.

yield five isomeric compounds (Fig. 1) that trivially are designated trehalulose, turanose, maltulose, leucrose and palatinose (Lichtenthaler \& Rönninger, 1990; Lichtenthaler et al., 1991; Immel \& Lichtenthaler, 1995). Until recently (Thompson et al., 2001a), there were no reports of the bacterial utilization of the five sucrose isomers. Indeed, the inability of mutans streptococci to metabolize these comparatively sweet disaccharides suggests their use as non-cariogenic substitutes for dietary sucrose (Ooshima et al., 1983, 1991; Ziesenitz et al., 1989; Minami et al., 1990; Peltroche-Llacsahuanga et al., 2001). In light of these reports, we were surprised to discover that K. pneumoniae readily utilized all five $\alpha$ D-glucosyl-D-fructoses as energy sources for growth (Thompson et al., 2001a, b), and that the enzymes encoded by the sucrose (scr) operon (Titgemeyer et al., 1996) did not participate in dissimilation of these compounds. Remarkably, the sucrose isomers and structurally related $\alpha$-glucosides (including maltose, isomaltose, maltitol and methyl $\alpha$-D-glucoside) are first translocated by an $\alpha$-glucoside-specific EII(CB) transport protein, and the accumulated 6 -phospho- $\alpha$-D-glucosides are hydrolysed by a metal-requiring, $\mathrm{NAD}^{+}$-dependent phosphoglucosyl hydrolase belonging to family 4 of the glycosylhydrolase superfamily (Henrissat, 1991). In K. pneumoniae, the genes for the EII $(\mathrm{CB})$ transport protein $(a g l A)$ and the phospho- $\alpha$-glucosidase $(a g l B)$ lie adjacent, and are chromosomally encoded (Thompson et al., 2001b).
Fusobacteria are Gram-negative anaerobic rods that are usually described as weakly or asaccharolytic, and most species, including Fusobacterium nucleatum, use amino acids as fermentable energy sources (Robrish et al., 1987; Robrish \& Thompson, 1990). The products of metabolism (acetic, butyric and propionic acids) may penetrate periodontal tissue, thereby contributing to the aetiology of gingivitis and periodontal disease. In contrast to other species, F. mortiferum ferments an extraordinarily wide variety of carbohydrates (Robrish et al., 1991). Previously, in studies of maltose metabolism in F. mortiferum, we cloned and expressed a gene $(\mathrm{malH})$ whose deduced sequence exhibits $\sim 75 \%$ residue identity with the phospho- $\alpha$-glucosidase of $K$. pneumoniae (Thompson et al., 1995; Bouma et al., 1997). In the present report, we show that the gene adjacent to malH (designated malB) also encodes a putative EII $(\mathrm{CB})$ protein that is $\sim 60 \%$ identical with AglA of K. pneumoniae. Coincident with our studies, publication of the complete genome sequence of enterohaemorrhagic E. coli O157:H7 (Perna et al., 2001) also revealed two adjacent genes with extensive homology to those found in K. pneumoniae. It was of interest, therefore, to determine whether possession of these genetic elements would also permit growth of $F$. mortiferum and E. coli $\mathrm{O} 157: \mathrm{H} 7$ on the five isomers of sucrose. Our findings are summarized in this communication. Additionally, we describe the purification, and some unexpected properties, of the phospho- $\alpha$ - 
glucosidase $(\mathrm{MalH})$ that catalyses the hydrolysis of phosphorylated sucrose isomers in F. mortiferum.

\section{METHODS}

Materials and reagents. Sucrose isomers were obtained from the following sources: trehalulose, Südzucker, Mannheim/ Ochsenfurt; turanose, Pfanstiehl Laboratories; maltulose, TCI America; leucrose, Fluka; palatinose, Wako Chemicals. Other sugars and glucosides were purchased from Sigma and Pfanstiehl Laboratories. Phosphorylated derivatives were biosynthesized via the PEP:PTS of permeabilized (palatinosegrown) cells of $K$. pneumoniae and were purified by $\mathrm{Ba}^{2+} /$ ethanol precipitation, ion-exchange and paper chromatography (Thompson et al., 2001a). The chromogenic and fluorogenic substrates $p$-nitrophenyl $\alpha$-D-glucopyranoside 6 phosphate (pNP- $\alpha$-G6P), $p$-nitrophenyl $\beta$-D-glucopyranoside 6-phosphate (pNP- $\beta$-G6P) and 4-methylumbelliferyl $\alpha$-Dglucopyranoside- 6 -phosphate (4-MU- $\alpha-\mathrm{G} 6 \mathrm{P})$ were prepared by selective phosphorylation (at $\mathrm{C} 6-\mathrm{OH}$ ) of the parent glucosides with phosphorus oxychloride in trimethyl phosphate containing small proportions of water (Thompson et al., 1995). Glucose-6-phosphate dehydrogenase (G6PDH, EC 1.1.1.49) and hexokinase (HK, EC 2.7.1.1) were purchased from Boehringer Mannheim, and Ultrogel AcA-44 and TrisAcryl M-DEAE from Sigma.

Bacterial strains and culture media. K. pneumoniae ATCC 23357, E. coli O157:H7 (EDL 933) and F. mortiferum ATCC 25557 were obtained from the American Type Culture Collection. K. pneumoniae and E. coli O157:H7 were grown in a medium of the following composition (per litre): $\mathrm{Na}_{2} \mathrm{HPO}_{4}, 7 \cdot 1 \mathrm{~g} ; \mathrm{KH}_{2} \mathrm{PO}_{4}, 1.5 \mathrm{~g} ;\left(\mathrm{NH}_{4}\right)_{2} \mathrm{SO}_{4}, 3 \mathrm{~g}$; $\mathrm{MgSO}_{4} \cdot 7 \mathrm{H}_{2} \mathrm{O}, 0 \cdot 1 \mathrm{~g} ; \mathrm{FeSO}_{4} \cdot 7 \mathrm{H}_{2} \mathrm{O}, 5 \mathrm{mg}$. Filter-sterilized sugars were added to autoclaved media $(\mathrm{pH} \mathrm{7 \cdot 4)}$ to a final concentration of $4 \mathrm{~g}$ per litre. Cells of $K$. pneumoniae were grown in standing cultures, but E. coli $\mathrm{O} 157: \mathrm{H} 7$ was grown with vigorous aeration on a rotary shaker ( $\sim 250$ r.p.m.). E. coli PEP43(pCB4.11) was grown with aeration in LuriaBertani (LB) medium supplemented with $50 \mu \mathrm{g}$ kanamycin $\mathrm{ml}^{-1}$. F. mortiferum was grown anaerobically (GasPak, $\mathrm{BBL}$ ) in a medium comprising (per litre): Tryptone (Difco), $17 \mathrm{~g}$; Protease Peptone (Difco), $3 \mathrm{~g} ; \mathrm{Na}_{2} \mathrm{HPO}_{4}, 2.5 \mathrm{~g} ; \mathrm{NaCl}$, $5 \mathrm{~g}$; final $\mathrm{pH} 7 \cdot 3$.

DNA sequence analysis. Automated DNA sequencing incorporating Big Dye terminators was used to sequence malB, and an adjacent upstream gene (malR), directly from genomic DNA of F. mortiferum. From data previously reported by Bouma et al. (1997), a reverse primer 1R1 (5'-AACTCTCTCTAACTTGTGGTACTGAAAGTC-3') was designed to obtain initial sequence information. Subsequent data were obtained by the primer synthesis and the chromosomal 'walking' technique. PCR primers were designed for sequencing of the second strand, and for amplification (from genomic DNA) of the fragment encoding the two genes by use of Taq DNA polymerase. The amplicon was cloned into the TOPO TA cloning vector (Invitrogen). All sequencing was performed by BioServe Biotechnologies (Laurel, MD, USA), and the MacVector 7.0 sequence analysis package (Genetics Computer Group, Madison, WI, USA) was used to assemble and analyse the data.

Metabolism of sugars by washed cells of $\boldsymbol{F}$. mortiferum. To maintain anaerobic conditions, centrifuge tubes were flushed with a gas mixture $\left(5 \% \mathrm{CO}_{2}, 5 \% \mathrm{H}_{2}, 90 \% \mathrm{~N}_{2}\right.$, by vol.) prior to harvesting of the sucrose-grown cells $(5000 \mathrm{~g}$ for $10 \mathrm{~min}$ at $5{ }^{\circ} \mathrm{C}$ ). The supernatant fluid was discarded, and the cell pellet was resuspended as quickly as possible in $30 \mathrm{ml}$ anaerobically prepared wash solution $[50 \mathrm{mM}$ potassium phosphate buffer ( $\mathrm{pH} 7$ ) containing $1 \mathrm{mM} \mathrm{MgCl}{ }_{2}$ ]. After centrifugation, the washed cells were resuspended in $5 \mathrm{ml}$ wash buffer, and the mixture was maintained at $0{ }^{\circ} \mathrm{C}$ under anaerobic conditions until required. For studies of disaccharide utilization, the washed cells (equivalent to $30 \mathrm{mg}$ total cell protein) were added to $10 \mathrm{ml}$ of wash buffer containing the desired sugar (sucrose or isomer) at a final concentration of $10 \mathrm{mM}$. The cell suspensions were incubated at $37^{\circ} \mathrm{C}$ in $100 \mathrm{ml}$ serum bottles filled with anaerobic gas and, at intervals, $1 \mathrm{ml}$ samples were withdrawn by insertion of a gas-flushed tuberculin syringe through the butyl rubber cap. The cells were removed by filtration through Millex-GS filter units $(0.22 \mu \mathrm{m}$ pore size; Millipore) and filtrates were collected. Samples were heated in $1 \mathrm{M} \mathrm{HCl}$ for $1 \mathrm{~h}$ at $100{ }^{\circ} \mathrm{C}$, cooled, and neutralized with $1 \mathrm{M} \mathrm{KOH}$. Glucose (equivalent to disaccharide remaining) was determined by the ATP-G6PDH/HK-NADP ${ }^{+}$coupled enzyme assay.

Preparation and analysis of $\boldsymbol{F}$. mortiferum extracts. Cells of $F$. mortiferum grown on the different sugars were harvested from $400 \mathrm{ml}$ anaerobic culture. The cell pellets $(\sim 1-2 \mathrm{~g}$ wet weight $)$ were resuspended with 3 vols $25 \mathrm{mM}$ Tris/ $\mathrm{HCl}$ buffer $(\mathrm{pH} 7 \cdot 5)$ containing $0.1 \mathrm{mM} \mathrm{NAD}{ }^{+}$and $1 \mathrm{mM} \mathrm{M} \mathrm{ml}_{2}$ (designated TNM buffer). The cells were disrupted by sonication at $0{ }^{\circ} \mathrm{C}$ $(6 \times 15 \mathrm{~s}$ bursts in a Branson instrument, model 185), and centrifuged at 14000 r.p.m. for $20 \mathrm{~min}$ at $5^{\circ} \mathrm{C}$ in an Eppendorf bench-top instrument. The clarified supernatants were assayed for S6PH, FK and phospho- $\alpha$-glucosidase activities.

Enzyme assays. The activities of S6PH, FK and phospho- $\alpha-$ glucosidase (with disaccharide phosphate substrates) were determined from the formation of glucose, fructose 6phosphate and G6P, respectively, in the appropriate reaction mixture. Production of the three metabolites was coupled to the enzymic reduction of $\mathrm{NADP}^{+}$(measured as $A_{340}$ ), and rates were determined in a Beckman DU 640 recording spectrophotometer. In all calculations, a molar absorption coefficient $(\varepsilon)$ of $6220 \mathrm{M}^{-1} \mathrm{~cm}^{-1}$ was assumed for NADPH.

$\mathrm{S} 6 \mathrm{PH}$. This enzyme catalyses the hydrolysis of both sucrose 6-phosphate (to G6P and fructose) and sucrose (to glucose and fructose), albeit with significantly different $K_{\mathrm{m}}$ for the two compounds $(0 \cdot 1 \mathrm{mM}$ and $\sim 100 \mathrm{mM}$, respectively; see Thompson et al., 1992). Because of the limited supply of sucrose 6-phosphate, sucrose was used as substrate for the spectrophotometric assay of $\mathrm{S} 6 \mathrm{PH}$ in cell extracts. The standard $1 \mathrm{ml}$ assay contained: $0 \cdot 1 \mathrm{M}$ potassium phosphate buffer ( $\mathrm{pH} \mathrm{7.2)}$; $50 \mathrm{mM}$ sucrose; $5 \mathrm{mM} \mathrm{ATP} ; 10 \mathrm{mM}$ $\mathrm{MgCl}_{2} ; 1 \mathrm{mM} \mathrm{NADP}{ }^{+}, \sim 3 \mathrm{U}$ each of $\mathrm{G} 6 \mathrm{PDH} / \mathrm{HK}$, and cell extract.

FK. Activity was determined in a similar mixture to that used for $\mathrm{S} 6 \mathrm{PH}$, containing $10 \mathrm{mM}$ fructose as substrate, $3 \mathrm{U}$ $\mathrm{G} 6 \mathrm{PDH}$ and $5 \mathrm{U}$ phosphoglucose isomerase.

Phospho- $\alpha$-glucosidase (MalH). Activity was determined by two methods in which either chromogenic analogues or phosphorylated disaccharides served as substrates. Cofactors $\mathrm{NAD}^{+}$and $\mathrm{Mn}^{2+}$ were included in both reaction mixtures. Throughout the purification of $\mathrm{MalH}$, enzyme activity was determined in a discontinuous assay with pNP- $\alpha-\mathrm{G} 6 \mathrm{P}$ and pNP- $\beta$-G6P as substrates. The $2 \mathrm{ml}$ reaction mixture (at $37^{\circ} \mathrm{C}$ ) contained: $50 \mathrm{mM}$ Tris/ $\mathrm{HCl}$ buffer $(\mathrm{pH} 7.5)$; $0.5 \mathrm{mM} \mathrm{NAD}^{+}$; $1 \mathrm{mM} \mathrm{MnCl}$; and $0.5 \mathrm{mM}$ of the chromogenic substrate. After enzyme addition, samples $(0.25 \mathrm{ml})$ were removed at intervals throughout a 3 min period of incubation, and were immediately added to $0.75 \mathrm{ml} 0.5 \mathrm{M} \mathrm{Na}_{2} \mathrm{CO}_{3}$ solution containing $0 \cdot 1 \mathrm{M}$ EDTA to stop the reaction. The $A_{400}$ was 


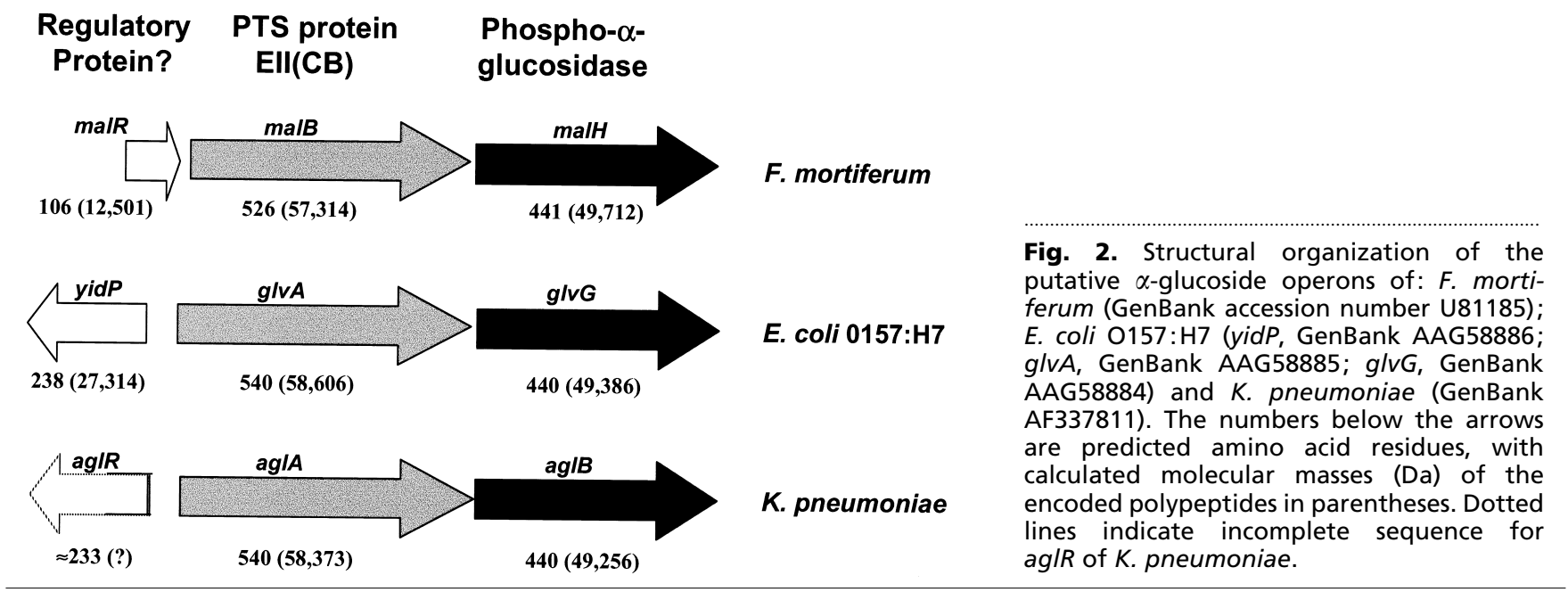

measured, and the amount of pNP formed (substrate hydrolysed) was calculated from the molar absorption coefficient of the yellow $p$-nitrophenolate anion, $\varepsilon=18300 \mathrm{M}^{-1} \mathrm{~cm}^{-1}$. A continuous $\mathrm{NADP}^{+}$-coupled assay was used to measure G6P formed by MalH-catalysed hydrolysis of phosphorylated disaccharides. The assay mixture contained in $1 \mathrm{ml}: 0 \cdot 1 \mathrm{M}$ HEPES buffer (pH 7.5); $1 \mathrm{mM} \mathrm{MgCl} ; 1 \mathrm{mM} \mathrm{MnCl}$; $1 \mathrm{mM}$ $\mathrm{NAD}^{+} ; 1 \mathrm{mM} \mathrm{NADP}{ }^{+} ; 2 \mathrm{mM}$ disaccharide phosphate, $3 \mathrm{U}$ G6PDH and purified MalH (35 $\mu$ g protein).

Purification of MalH from E. coli PEP43(pCB4.11). A $2 \cdot 2 \mathrm{~kb}$ Sau3AI chromosomal DNA fragment of F. mortiferum that includes the malH gene and its promoter has previously been cloned and the enzyme has been expressed from plasmid pCB4.11 (Bouma et al., 1997). This plasmid was transferred by electroporation to E. coli PEP43 $\Delta$ cel $\Delta(b g l-p h o)$ leu met $A$ or $B$ his rpsL lacZ $\Delta 4680$ lac $^{+}$arb $T^{+}$Tn10::bglA dTn10 cam :: ebgA5100 ebgR ${ }^{+}$L532 (B. G. Hall, Biology Department, University of Rochester, NY, USA, laboratory collection). E. coli PEP43 expresses no phospho- $\beta$-glucosidases because the $c e l$ and $b g l G F B$ operons have been deleted, $b g l A$ is disrupted by $\operatorname{Tn} 10$ and the asc operon is cryptic.

Cells of E. coli PEP43(pCB4.11) ( $25 \mathrm{~g}$ wet weight) were resuspended with $40 \mathrm{ml}$ TNM buffer, and the organisms were disrupted by $2 \times 1.5$ min sonication with a Branson model 350 instrument. The preparation was clarified by ultracentrifugation $\left(180000 \mathrm{~g}\right.$ for $2 \mathrm{~h}$ at $\left.5^{\circ} \mathrm{C}\right)$, and the supernatant fluid was dialysed against 4 litres of TNM buffer. The dialysed

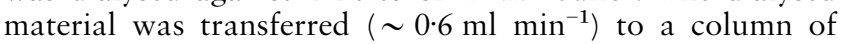
TrisAcryl M-DEAE $(2.6 \times 10 \mathrm{~cm})$ that had been equilibrated with TNM buffer. The column was washed to elute nonadsorbed material, and then $\mathrm{MalH}$ activity was eluted with $500 \mathrm{ml}$ of a linear, increasing concentration gradient of $\mathrm{NaCl}$ $(0-150 \mathrm{mM})$ in TNM buffer. Fractions of $5 \mathrm{ml}$ were collected, and those containing highest MalH activity (54-65 inclusive) were pooled and concentrated in an Amicon pressure cell to $\sim 3 \mathrm{ml}$. The concentrated sample was transferred

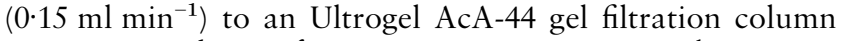
$(1.6 \times 94 \mathrm{~cm}$; linear fractionation range, $10-130 \mathrm{kDa})$ previously equilibrated with TNM buffer containing $0 \cdot 1 \mathrm{M} \mathrm{NaCl}$. Fractions of $2 \mathrm{ml}$ were collected, and tetrameric $\mathrm{MalH}$ ( $\sim 200 \mathrm{kDa})$ was eluted at the void volume of the column. Fractions that contained a single protein by SDS-PAGE (47-50, inclusive) were pooled, and concentrated to yield $\sim 5 \mathrm{mg}$ purified MalH [specific activity $2.9 \mu \mathrm{mol}$ pNP- $\alpha$-G6P hydrolysed $\min ^{-1}$ (mg protein $)^{-1}$.

Analytical methods. Protein concentrations were determined by the BCA protein assay (Pierce). The Novex X-Cell system was used for both native (nonreducing) and SDS-PAGE. For SDS-PAGE experiments, precast NuPage (4-12\%) Bistris gels and MES-SDS running buffer $(\mathrm{pH} 7 \cdot 3$ ) were used with Novex Mark 12 protein size standards. Proteins were stained with Coomassie brilliant blue R-250. Electrophoresis of cell extracts under nonreducing conditions was carried out at $10{ }^{\circ} \mathrm{C}$ in Tris/glycine $(4-20 \%)$ precast gels from Novex, with Tris/glycine (pH 8.3) supplemented with $1 \mathrm{mM} \quad \mathrm{MnCl}_{2}$ and $0.1 \mathrm{mM} \mathrm{NAD}{ }^{+}$as the running buffer. For detection of phospho- $\alpha$-glucosidase activity, the gel was immersed in $30 \mathrm{ml}$ of a solution that contained $25 \mathrm{mM}$ Tris/ $\mathrm{HCl}$ buffer $(\mathrm{pH} 7 \cdot 5)$; $1 \mathrm{mM} \mathrm{MnCl}_{2} ; 0 \cdot 1 \mathrm{mM} \mathrm{NAD}^{+}$and $0.1 \mathrm{mM} 4 \mathrm{MU}-\alpha-\mathrm{G} 6 \mathrm{P}$. After $\sim 5$ min incubation, the gel was photographed under longwave UV light with Ektopan Kodak film (2 min exposure with a green filter). For Western blot analysis, proteins in the cell extracts together with pre-stained markers (SeeBlue from Novex), were first separated by SDS-PAGE and then transferred to a nitrocellulose membrane. Immunodetection of phospho- $\alpha$-glucosidase was performed with polyclonal antibody to MalH from F. mortiferum as described previously (Thompson et al., 1995). Molecular dynamics simulations and procedures for the determination of solvent-accessible surfaces have been described previously (Immel \& Lichtenthaler, 1995; Thompson et al., 2001b).

\section{RESULTS}

Gene organization in $F$. mortiferum, $K$. pneumoniae and $E$. coli $0157: \mathrm{H7}$

The genes that constitute the putative $\alpha$-glucoside operons, and their organization in the three bacterial species, are shown in Fig. 2. In K. pneumoniae, adjacent chromosomal genes aglA and $a g l B$ encode, respectively, an $\mathrm{EII}(\mathrm{CB})$ transport protein and phospho- $\alpha$-glucosidase. These proteins promote the phosphorylative translocation and hydrolysis of sucrose isomers by this organism (Thompson et al., 2001a, b). The partial 
Table 1. Enzyme activities in extracts prepared from cells of $F$. mortiferum grown previously on various carbohydrates

\begin{tabular}{|c|c|c|c|}
\hline \multirow[t]{2}{*}{ Growth sugar } & \multicolumn{3}{|c|}{ Enzyme specific activity $\dagger$} \\
\hline & Phospho- $\alpha$-glucosidase $\neq$ & FK $\mathbb{S}$ & S6PH \\
\hline Trehalulose* & $11 \cdot 6$ & $2 \cdot 6$ & $2 \cdot 2$ \\
\hline Sucrose & ND & $26 \cdot 3$ & $63 \cdot 4$ \\
\hline Turanose* & $3 \cdot 5$ & $0 \cdot 7$ & $1 \cdot 9$ \\
\hline Maltulose* & $3 \cdot 4$ & $1 \cdot 6$ & $1 \cdot 6$ \\
\hline Leucrose $^{*}$ & $12 \cdot 7$ & $2 \cdot 4$ & $6 \cdot 5$ \\
\hline Palatinose* & $3 \cdot 2$ & $1 \cdot 2$ & $4 \cdot 0$ \\
\hline Glucose & $\mathrm{ND}$ & $2 \cdot 1$ & ND \\
\hline Fructose & ND & $1 \cdot 0$ & $3 \cdot 6$ \\
\hline Maltose & $8 \cdot 5$ & $3 \cdot 1$ & $2 \cdot 8$ \\
\hline Methyl $\alpha$-D-glucoside & $23 \cdot 9$ & $\mathrm{ND}$ & $2 \cdot 8$ \\
\hline
\end{tabular}

* Sucrose isomers.

† The same cell extracts were used for the assay of the three enzyme activities; values are means of two separate assays. ND, No detectable activity.

$\ddagger$ nmol pNP- $\alpha$-G6P hydrolysed $\min ^{-1}$ (mg protein $)^{-1}$.

$\$$ nmol fructose phosphorylated $\min ^{-1}(\text { mg protein })^{-1}$.

$\|$ nmol sucrose hydrolysed $\min ^{-1}$ (mg protein $)^{-1}$.

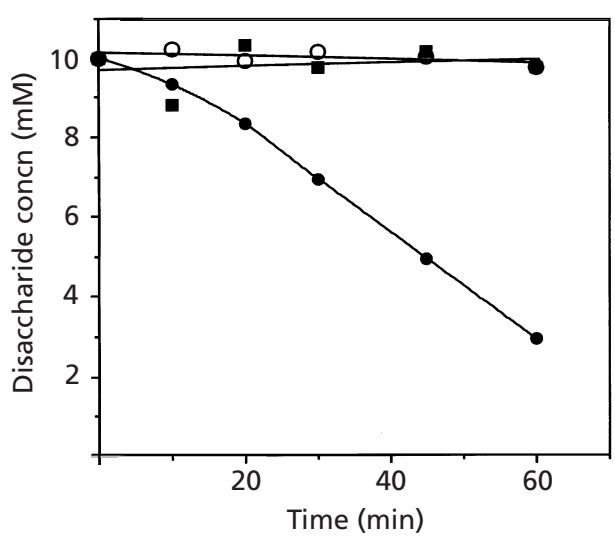

Fig. 3. Studies of the metabolism of sucrose and two of its isomers by sucrose-grown cells of $F$. mortiferum. Washed cells were resuspended, under anaerobic conditions, in buffered solution containing the disaccharides at an initial concentration of $10 \mathrm{mM}$. Samples were removed at intervals and residual disaccharide was determined by the enzymic assay of glucose produced by acid hydrolysis. 0 , Sucrose; $O$, turanose; palatinose.

sequence of the regulatory gene, aglR, was compiled from our own work, together with data obtained from the Washington University (St Louis) sequencing project of the K. pneumoniae genome (http://genome.wustl. edu). The recently published genome sequence of enterohaemorrhagic E. coli O157:H7 (Perna et al., 2001) revealed the same organization of the three genes (designated $y i d P, g l v A$ and $g l v G$ ) as described for $K$. pneumoniae. The amino acid sequence deduced from
Table 2. Expression of S6PH and FK during growth of $K$. pneumoniae on different sugars

\begin{tabular}{|lrc|}
\hline Growth sugar & \multicolumn{2}{c|}{ Enzyme specific activity } \\
\cline { 2 - 3 } & FK† & S6PH $\ddagger$ \\
\hline Trehalulose* $^{*}$ & 69 & 289 \\
Sucrose & 103 & 247 \\
Turanose* & 64 & 342 \\
Maltulose* & 54 & 170 \\
Leucrose* & 51 & 184 \\
Palatinose* & 87 & 289 \\
Maltose & 15 & 29 \\
Trehalose & 3 & ND \\
Melibiose & 9 & 18 \\
Cellobiose & 2 & 6 \\
Maltitol & 1 & 3 \\
Glucose & ND & 2 \\
Methyl $\alpha$-D-glucoside & 1 & ND \\
Galactose & 8 & 6 \\
\hline
\end{tabular}

ND, No detectable activity.

*Sucrose isomers.

† nmol fructose phosphorylated $\min ^{-1}$ (mg protein $)^{-1}$. $\ddagger$ nmol sucrose hydrolysed $\min ^{-1}(\text { mg protein })^{-1}$.

yidP of E. coli $\mathrm{O} 157: \mathrm{H} 7$ predicts a polypeptide of 238 residues that exhibits $91 \%$ overall identity with the 233 residues deduced by translation of the incomplete gene aglR of K. pneumoniae. At their N-termini, the products of aglR and yidP contain a helix-turn-helix (HTH) 

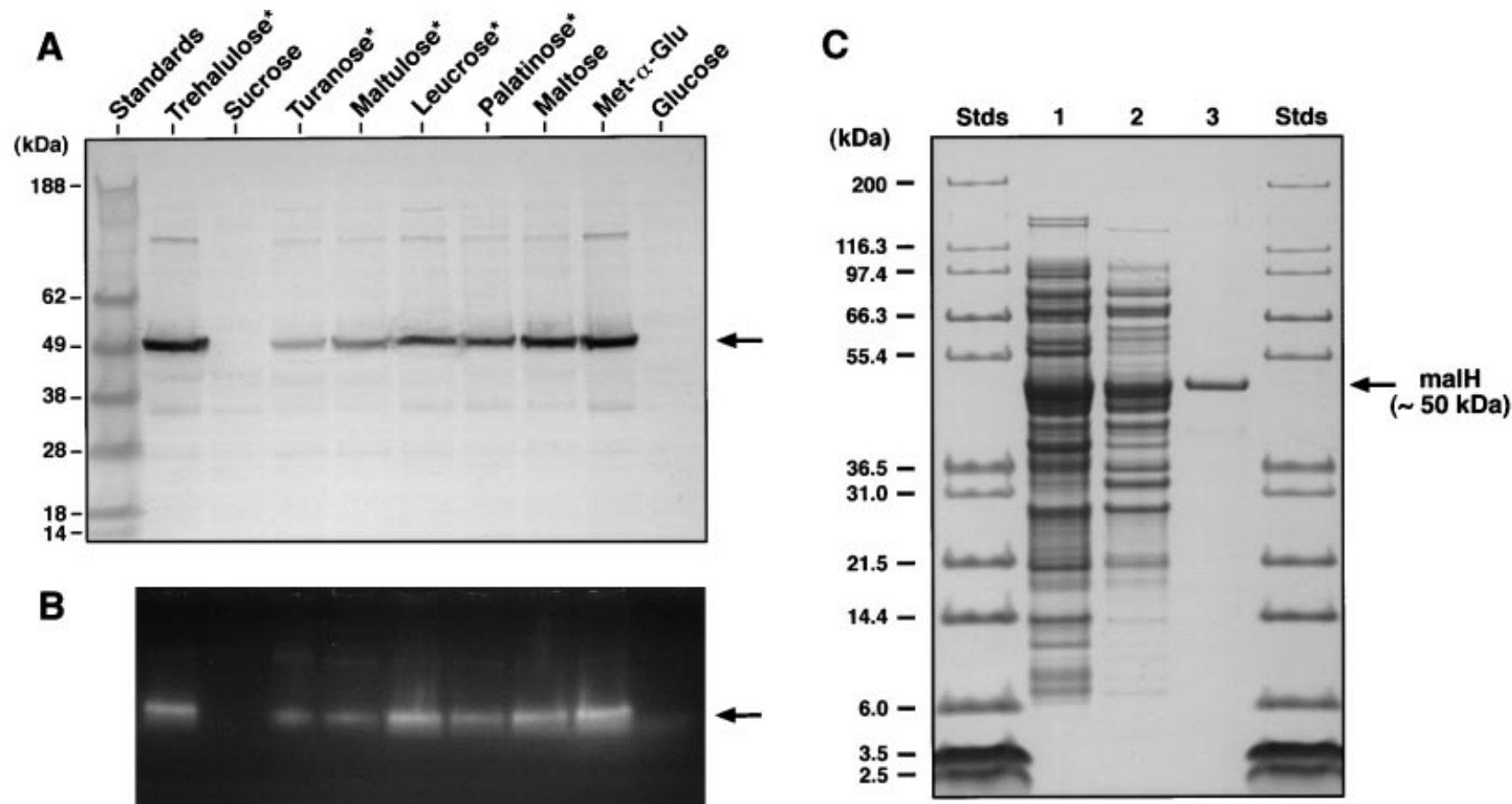

Fig. 4. Demonstration by PAGE of the expression, in situ activity, and purification of phospho- $\alpha$-glucosidase (MalH) from F. mortiferum. (A) Immunodetection of MalH expression during growth of $F$. mortiferum on different sugars, by Western blotting using polyclonal antibody to $\mathrm{MalH}$. Note the absence of immunoreactive polypeptide $(\sim 50 \mathrm{kDa}$, arrow) in the extract from sucrose-grown cells. (B) Zymogram demonstration of MalH activity in cell extracts by hydrolysis (arrow) of the fluorogenic substrate $4 \mathrm{MU} \alpha \mathrm{G} 6 \mathrm{P}$. Again, note the absence of fluorescence in the lane containing the extract from sucrose-grown cells. (C) Purification and determination of the molecular mass of MalH. Samples from each of the three stages of purification were denatured, and polypeptides were resolved by SDS-PAGE: lane 1, dialysed high-speed supernatant; lane 2, TrisAcryl M-DEAE; lane 3, purified MalH (molecular mass $\sim 50 \mathrm{kDa}$ ) obtained by AcA-44 gel filtration chromatography. The asterisks in panel A indicate sucrose isomers.

motif that assigns the two proteins to the GntR family of transcriptional regulators. The complete sequence of the phospho- $\alpha$-glucosidase gene (malH) of F. mortiferum, together with a partial sequence for the gene (malB), were described in an earlier report (Bouma et al., 1997). The entire sequences for malB, and the upstream gene (malR), have now been obtained by chromosome 'walking' (GenBank accession no. U81185). Translation of malR predicts a 106-residue polypeptide that shows extensive homology with the 13 members of the UPF0087 family of regulatory proteins.

\section{Sequence alignment of phospho- $\alpha$-glucosidase and EII(CB) proteins}

Alignment of the amino acid sequences predicted for the phospho- $\alpha$-glucosidase(s) and EIIs reveals a high degree of similarity among these proteins (data not shown). $\mathrm{MalH}$ from $F$. mortiferum exhibits $\sim 75 \%$ residue identity with the phosphoglucosyl hydrolase(s) from $E$. coli O157:H7 and K. pneumoniae. The EII(CB) transport protein of $F$. mortiferum (MalB) shows $\sim 60 \%$ amino acid identity throughout its length with GlvA and AglA in E. coli $\mathrm{O} 157: \mathrm{H} 7$ and K. pneumoniae, respectively. For the two enteric species, phospho- $\alpha$-gluc- osidase and $\mathrm{EII}(\mathrm{CB})$ proteins exhibit overall identities of $89 \%$ and $81 \%$, respectively. By sequence-based alignment (Henrissat, 1991) and signature pattern (P$\mathrm{X}$-[SA]-X-[LIVMFY] (2)-[QN]-X(2)-N-P-X(4)-[TA]$\mathrm{X}(9,10)-[\mathrm{KRD}]-\mathrm{X}-[\mathrm{LIV}]-[\mathrm{GN}]-\mathrm{X}-\mathrm{C})$, the three phospho$\alpha$-glucosidases can be assigned to family 4 of glycosylhydrolases (see http://www.expasy.ch/cgi-bin/lists? glycosid.txt and http://afmb.cnrs-mrs.fr/ cazy/ $\mathrm{CAZY}$ /index.html). By their composition and modular structure, proteins MalB, GlvA and AglA, can be assigned to the EII ${ }^{\mathrm{Gle} / \mathrm{Scr}}$ family of PTS transporters (Lengeler et al., 1994; Lanz \& Erni, 1998).

\section{Growth studies with F. mortiferum, K. pneumoniae and $E$. coli $0157: \mathrm{H7}$}

Growth studies were performed to determine if possession of the putative operons would permit growth of the three organisms on sucrose isomers and other $\alpha$ glucosides. Both K. pneumoniae and F. mortiferum showed excellent growth on all sugars tested, including glucose, fructose, methyl $\alpha$-glucoside, maltose, maltitol, sucrose and all five $\alpha$-D-glucosyl-D-fructoses. E. coli O157:H7 grew well on glucose, fructose, maltose and 
sucrose, but the pathogen was unable to grow on methyl $\alpha$-glucoside, maltitol or any of the sucrose isomers.

\section{Enzyme expression during growth of $\boldsymbol{F}$. mortiferum on sucrose and its isomers}

S6PH and ATP-dependent fructokinase (FK) are induced by growth of $F$. mortiferum on sucrose (Robrish et al., 1991; Thompson et al., 1992). Because sucrose and its isomers comprise the same hexose moieties, it was of interest to determine whether sucrose-grown cells of $F$. mortiferum would also metabolize the isomeric compounds. As expected, sucrose-grown cells readily fermented sucrose, but there was no detectable metabolism of the five isomers, including palatinose and turanose (Fig. 3). Furthermore, whereas sucrose-grown cells of $F$. mortiferum contained high levels of S6PH and FK activity (Table 1), after growth on the isomers, the activities of the two enzymes were not significantly greater than the constitutive levels found in glucose- or fructose-grown cells. These findings contrast markedly with the high levels of S6PH and FK that are expressed during growth of $K$. pneumoniae on the isomeric compounds (Table 2).

\section{Phospho- $\alpha$-glucosidase (MalH) is expressed during growth of $\boldsymbol{F}$. mortiferum on sucrose isomers}

From the results of fermentation studies and enzymic analyses (Fig. 3 and Table 1, respectively), it was evident that that dissimilation of the sucrose isomers by $F$. mortiferum was via a route that was separate from that encoded by the $s c r$ regulon. Because previous studies with K. pneumoniae (Thompson et al., 2001a) showed that growth on the sucrose isomers induced high-level expression of phospho- $\alpha$-glucosidase (AglB), the various cell extracts of $F$. mortiferum were accordingly assayed for phospho- $\alpha$-glucosidase $(\mathrm{MalH})$ activity (Table 1 ). Extracts prepared from organisms grown previously on the sucrose isomers and other $\alpha$-glucosides (e.g. maltose and methyl $\alpha$-glucoside) readily hydrolysed pNP- $\alpha$-G6P (Table 1). However, there was no detectable hydrolysis of the chromogenic analogue by similarly prepared extracts from organisms grown on glucose, fructose or sucrose. The results of a Western blot (Fig. 4A), performed with polyclonal antibody to $\mathrm{MalH}$, confirmed expression of the phospho- $\alpha$-glucosidase (molecular mass $\sim 50 \mathrm{kDa}$ ) during growth on sucrose isomers and other $\alpha$-glucosides. Significantly, the immunoreactive protein $(\mathrm{MalH})$ was not detectable in either sucrose- or glucose-grown cell extracts. The data presented in Fig. 4(B) established the co-identity of the immunoreactive polypeptide and the enzymically active protein. In this experiment, samples of the various cell extracts of $F$. mortiferum were electrophoresed under non-denaturing conditions, prior to in situ staining for phospho- $\alpha$-glucosidase activity using the fluorogenic substrate 4-MU- $\alpha$-G6P. The zymogram (Fig. 4B) yielded three significant results: (i) the intensely fluorescent aglycone (4-methylumbelliferone) was generated only
Table 3. Cofactor requirements for the hydrolysis of chromogenic substrates pNP- $\alpha$-G6P and pNP- $\beta$-G6P by purified MalH from $F$. mortiferum

Assay composition and procedures are described in Methods. $\mathrm{NAD}^{+}$, metal ions and chromogenic substrates were present at $1 \mathrm{mM}$ final concentration. Hydrolysis rates, expressed as $\mu \mathrm{mol}$ pNP formed $\min ^{-1}$ (mg protein $)^{-1}$, are the means of two determinations. ND, No detectable activity.

\begin{tabular}{|lcc|}
\hline \multirow{2}{*}{ Additions to assay } & \multicolumn{2}{c|}{ Activity with chromogenic analogue: } \\
\cline { 2 - 3 } & pNP- $\boldsymbol{\alpha}$-G6P & pNP- $\boldsymbol{\beta}$-G6P \\
\hline None & $\mathrm{ND}$ & $\mathrm{ND}$ \\
$\mathrm{NAD}^{+}$ & $0 \cdot 11$ & $0 \cdot 08$ \\
$\mathrm{Mn}^{2+}$ & 1.61 & $1 \cdot 19$ \\
$\mathrm{NAD}^{+}+\mathrm{Mn}^{2+}$ & $2 \cdot 91$ & 1.56 \\
$\mathrm{NAD}^{+}+\mathrm{Mg}^{2+}$ & $0 \cdot 39$ & $0 \cdot 16$ \\
$\mathrm{NAD}^{+}+\mathrm{Ni}^{2+}$ & $0 \cdot 51$ & 0.54 \\
$\mathrm{NAD}^{+}+\mathrm{Co}^{2+}$ & 1.47 & $2 \cdot 28$ \\
\hline
\end{tabular}

by those extracts that contained the immunoreactive protein $(\mathrm{MalH})$; (ii) formation of a single zone of fluorescence (at the same migration distance in the gel) provided evidence for only one species of phospho- $\alpha$ glucosidase in the extracts, and (iii) absence of fluorescence in lane 2 was consistent with the inability of $F$. mortiferum to express MalH during growth on sucrose.

\section{Purification, cofactor requirements, and substrate specificity of MalH}

The data presented thus far (although suggestive), did not establish a functional role for $\mathrm{MalH}$ in dissimilation of the $\alpha$-D-glucosyl-D-fructoses by F. mortiferum. Clearly, it was necessary to purify $\mathrm{MalH}$, and demonstrate hydrolysis of either free or phosphorylated derivatives of the isomers by the enzyme. To this end a plasmid (pCB4.11) containing the cloned malH gene under its own promoter (Bouma et al., 1997) was transformed into E. coli strain PEP43. Importantly, the latter strain is deficient in all phospho- $\beta$-glucosidase activities, and an extract of these cells is unable to hydrolyse the chromogenic substrate $\mathrm{pNP}-\beta$-G6P. Unexpectedly, after expression of $\mathrm{MalH}$ in E. coli PEP43(pCB4.11), the resultant cell extract caused the hydrolysis of both pNP$\alpha$ - and pNP- $\beta$-G6P. Hydrolysis of both compounds was observed throughout purification of $\mathrm{MalH}$ (Fig. 4C), and the same cofactors (divalent metal ion and $\mathrm{NAD}^{+}$) were required for cleavage of both chromogenic substrates by electrophoretically pure enzyme (Table 3 ). We conclude that a single protein $(\mathrm{MalH})$ is responsible for the hydrolysis of the two stereomers, pNP- $\alpha$-G6P and pNP- $\beta$-G6P. Studies of substrate specificity revealed that neither purified $\mathrm{MalH}$, nor extracts prepared from cells of $F$. mortiferum grown previously on the isomers, were 
Table 4. Hydrolysis of phosphorylated sucrose isomers by MalH from F. mortiferum

Assay procedures are described in Methods. Phosphorylated compounds were present at a concentration of $2 \mathrm{mM}$. Enzyme activity is expressed as $\mu \mathrm{mol}$ G6P formed $\mathrm{min}^{-1}$ (mg protein $)^{-1}$; values are means of two determinations. ND, No detectable hydrolysis.

\begin{tabular}{|c|c|}
\hline Disaccharide phosphate in assay & Specific activity \\
\hline Trehalulose- $6^{\prime} \mathrm{P}^{*}$ & $0 \cdot 15$ \\
\hline Sucrose-6P & ND \\
\hline Turanose- $6^{\prime} \mathrm{P}^{*}$ & $0 \cdot 68$ \\
\hline Maltulose- $6^{\prime} \mathrm{P}^{*}$ & $0 \cdot 40$ \\
\hline Leucrose- $6^{\prime} \mathrm{P}^{*}$ & $0 \cdot 08$ \\
\hline Palatinose- $6^{\prime} \mathrm{P}^{*}$ & $0 \cdot 11$ \\
\hline Maltose- $6^{\prime} \mathrm{P}$ & $0 \cdot 15$ \\
\hline Cellobiose- $6^{\prime} \mathrm{P} \dagger$ & ND \\
\hline Gentiobiose- $6^{\prime} \mathrm{P} \neq$ & ND \\
\hline
\end{tabular}

*Sucrose isomers.

† Cellobiose: 4-O- $\beta$-D-glucopyranosyl-D-glucopyranose.

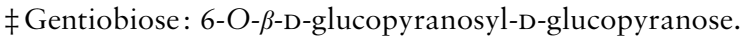

able to hydrolyse the free (non-phosphorylated) forms of the isomeric compounds (data not shown). However, the 6'-O-phosphorylated derivatives of the five $\alpha$-Dglucosyl-fructoses were hydrolysed by $\mathrm{MalH}$ (Table 4), albeit at a rate considerably slower than that determined for the $\alpha$-linked chromogenic substrate, pNP- $\alpha$-G6P. Significantly, sucrose 6-phosphate itself was not a substrate for $\mathrm{MalH}$, and the enzyme also failed to hydrolyse $\beta$-O-linked phosphorylated disaccharides such as cellobiose $6^{\prime}$-phosphate and gentiobiose $6^{\prime}$ phosphate (Table 4).

\section{DISCUSSION}

Here we report the metabolism of sucrose isomers by $F$. mortiferum, and provide insight into the enzymic and genetic basis for growth on these isomers. Presently, F. mortiferum and K. pneumoniae are the only organisms known to ferment the five $\alpha$-D-glucosyl-D-fructoses. Earlier we showed that $\mathrm{MalH}$ from F. mortiferum hydrolysed maltose 6'-phosphate (Thompson et al., 1995), and now we provide evidence for the cleavage of the phosphorylated isomers of sucrose by this enzyme. The phospho- $\alpha$-glucosidase gene $(\mathrm{malH})$ is adjacent to the gene malB, whose now completed sequence predicts a polypeptide that in size, domain structure, and conserved motifs (GITE and CATRLR) is characteristic of an EII(CB) transporter of the PEP:PTS. Genes malB and $m a l H$ are homologous to aglA and aglB, respectively, of K. pneumoniae. We suggest that the polypeptides encoded by these genetic elements are required for growth of F. mortiferum and K. pneumoniae on the isomers of sucrose and related $\alpha$-glucosides, including maltose. A common feature of these genetic units is the absence of a gene encoding a third (and usually sugarspecific) protein (EIIA) that is required for operation of all PTS systems. Interestingly, both sucrose:PTS and trehalose:PTS operons in Bacillus subtilis also lack the expected EIIA genes and, for these systems, it is believed that EIIA ${ }^{\text {Gle }}$ can serve as substitute (Sutrina et al., 1990; Dahl, 1997). A similar cross-complementation may also occur between the EIIA ${ }^{\mathrm{Glc}}$ and EII(CB) proteins of $F$. mortiferum and K. pneumoniae to yield a functional $\alpha$ glucoside:PTS in these species.

Proteins encoded by the $s c r$ operons of $K$. pneumoniae and F. mortiferum are expressed during growth of both organisms on sucrose (Sprenger \& Lengeler, 1988; Thompson et al., 1992). Hydrolysis of sucrose 6phosphate by S6PH yields G6P and fructose, and for $K$. pneumoniae, fructose is believed to be the inducer of the scr operon (Jahreis \& Lengeler, 1993). Hydrolysis of the phosphorylated isomers by AglB of K. pneumoniae also yields G6P and fructose, and formation of the latter ketohexose is consistent with the high levels of S6PH and FK present in cells grown on the isomers (Table 2). Surprisingly, similar studies with F. mortiferum showed that, for this organism, growth on the isomeric compounds did not induce significant expression of either S6PH or FK (Table 1). These findings explain why these cells were unable to metabolize sucrose, and additionally, the data point to sucrose 6-phosphate (rather than fructose) as the likely inducer of the $\mathrm{scr}$ operon in F. mortiferum.

\section{Substrate specificity and hydrolysis of chromogenic substrates by MalH}

$\mathrm{MalH}$ is an oligomeric protein comprising four identical subunits (molecular mass $\sim 50 \mathrm{kDa}$ ) that, by sequencebased alignment, is assigned to family 4 of the glycosylhydrolase superfamily. As reported for other members of this unusual family, MalH is inherently unstable and $\mathrm{Mn}^{2+}$ and $\mathrm{NAD}^{+}$are prerequisite cofactors for activity (Nagao et al., 1988; Thompson et al., 1998, 1999; Raasch et al., 2000). Whether the nucleotide and metal ion fulfil catalytic or structural functions has not been ascertained for any member of family 4. Phosphorylation at O-6 of the glucosyl moiety of the isomers is necessary for substrate cleavage, and $\mathrm{MalH}$ is unable to hydrolyse the corresponding non-phosphorylated compounds. MalH is also exacting with respect to the $\alpha$ $O$ linkage of its PTS-derived substrates (see below) and, because there is no detectable hydrolysis of $\beta$-O-linked stereomers such as cellobiose $6^{\prime}$-phosphate and gentiobiose 6 '-phosphate (Table 4), the enzyme may reasonably be classified as a phospho- $\alpha$-glucosidase. In this context, it is not clear why MalH should hydrolyse both $\mathrm{pNP}-\alpha-\mathrm{G} 6 \mathrm{P}$ and $\mathrm{pNP}-\beta$-G6P with comparable efficiency (Table 3). Co-purification of $\mathrm{MalH}$ with a phospho- $\beta$ glucosidase resident in the host (E. coli PEP43) can be discounted because of gene inactivation or crypticity, and analysis of the final preparation by SDS-PAGE provided evidence for only a single polypeptide. That the same cofactors should also be required for catalysis is further evidence that the same enzyme hydrolyses both $\alpha$ - and $\beta$-forms of the chromogenic compound(s). 
Unlike the phosphorylated sucrose isomers (where G6P is linked to a fructose moiety), the essential G6P moiety of the chromogenic substrates is attached to $p$-nitrophenol. Perhaps the aromatic aglycone exerts an effect (electron-withdrawing?) upon the O-linkage such that $\alpha / \beta$ conformation is no longer a determinant of substrate specificity. It is of comparative interest to note that cellobiose-6-phosphate hydrolase (CelF) from E. coli is also a member of glycosylhydrolase family 4 (Thompson et al., 1999). In contrast to $\mathrm{MalH}$, this $\mathrm{NAD}^{+}-$and metal-dependent phospho- $\beta$-glucosidase hydrolyses only $\mathrm{pNP}-\beta-\mathrm{G} 6 \mathrm{P}$.

\section{Molecular basis for substrate recognition by MalH}

Sucrose 6-phosphate and its phosphorylated isomers are not commercially available, but all of these derivatives were recently prepared in our laboratory (Thompson et al., 2001a). Studies of substrate specificity showed that whereas MalH hydrolysed all of the phosphorylated isomers, the enzyme failed to hydrolyse sucrose 6phosphate itself. Insight into the molecular basis for this remarkable discrimination among potential substrates was gained by molecular dynamics simulations, which revealed the probable solution-state geometries of the various disaccharide phosphates (Thompson et al., 2001b). Molecular dynamics simulations and determination of solvent-accessible surfaces indicate pronounced conformational differences between sucrose 6-phosphate and its five isomeric $6^{\prime}$-phosphates. By virtue of an interresidue water bridge between Glc-2-O ${ }^{\cdots} \mathrm{H}_{2} \mathrm{O} \cdots \mathrm{O}-$ 1-Fru, both sucrose and sucrose 6-phosphate assume a compact, globular shape in solution (Immel \& Lichtenthaler, 1995; Thompson et al., 2001b). This water bridge is not present in the 6'-phosphoglucosyl-fructoses and, in consequence, the phosphorylated isomers adopt a more linear (extended) molecular geometry. The specificity of $\mathrm{MalH}$ for the isomeric phosphates presumably reflects recognition by the enzyme's binding domain of both the shape and the molecular lipophilicity potential of the contact surfaces of these particular molecules (Thompson et al., 2001b).

\section{Conclusions}

Both $F$. mortiferum and $K$. pneumoniae readily metabolize the five isomers of sucrose. In contrast, E. coli O157:H7 (which grows well on sucrose) failed to grow on any of the isomeric compounds. These results were surprising, because this enterohaemorrhagic strain has three genes ( $y i d P, g l v A$ and $g l v G)$ whose organization and deduced amino acid sequences are virtually identical to those of $a g l R$, aglA and $a g l B$, respectively, in $K$. pneumoniae. Although contrary to expectation, the results obtained for E. coli O157: H7 were nevertheless important. First, the data established for E. coli O157:H7 (as for the other species), that the sucrosePTS/S6PH pathway is neither induced by, nor does it provide a route for dissimilation of, sucrose isomers. Secondly, the data indicate that possession of genes encoding $\alpha$-glucoside-specific EII(CB) and phospho- $\alpha$ - glucosidase (while necessary), may not be entirely sufficient for dissimilation of $\alpha$-D-glucosyl-D-fructoses by micro-organisms.

\section{ACKNOWLEDGEMENTS}

We thank Carolyn L. Bouma for construction and provision of pCB4.11. We would like to thank Jack London and Edith C. Wolff for their review and constructive criticisms of this article. We express appreciation to Professor Frieder W. Lichtenthaler for his encouragement and interest in our investigation.

\section{REFERENCES}

Bouma, C. L., Reizer, J., Reizer, A., Robrish, S. A. \& Thompson, J. (1997). 6-Phospho- $\alpha$-D-glucosidase from Fusobacterium mortiferum: cloning, expression, and assignment to family 4 of the glycosylhydrolases. J Bacteriol 179, 4129-4137.

Chen, Y.-Y. M. \& LeBlanc, D. J. (1992). Genetic analysis of $s c r A$ and scrB from Streptococcus sobrinus 6715. Infect Immun 60, 3739-3746.

Dahl, M. K. (1997). Enzyme II ${ }^{\mathrm{Glc}}$ contributes to trehalose metabolism in Bacillus subtilis. FEMS Microbiol Lett 148, 233-238.

Fouet, A., Arnaud, M., Klier, A. \& Rapoport, G. (1987). Bacillus subtilis sucrose-specific enzyme II of the phosphotransferase system: expression in Escherichia coli and homology to enzymes II from enteric bacteria. Proc Natl Acad Sci U S A 84, 8773-8777.

Henrissat, B. (1991). A classification of glycosyl hydrolases based on amino acid sequence similarities. Biochem J 280, 309-316.

Immel, S. \& Lichtenthaler, F. W. (1995). Molecular modeling of saccharides. 7. The conformation of sucrose in water: a molecular dynamics approach. Liebigs Ann Chem 1925-1937.

Jahreis, K. \& Lengeler, J. W. (1993). Molecular analysis of two ScrR repressors and of a ScrR-FruR hybrid repressor for sucrose and D-fructose specific regulons from enteric bacteria. Mol Microbiol 9, 195-209.

Lanz, R. \& Erni, B. (1998). The glucose transporter of the Escherichia coli phosphotransferase system. Mutant analysis of the invariant arginines, histidines, and domain linker. J Biol Chem 273, 12239-12243.

Lengeler, J. W., Jahreis, K. \& Wehmeier, U. F. (1994). Enzymes II of the phosphoenolpyruvate-dependent phosphotransferase systems: their structure and function in carbohydrate transport. Biochim Biophys Acta 1188, 1-28.

Lichtenthaler, F. W. \& Rönninger, S. (1990). $\alpha$-D-GlucopyranosylD-fructoses: distribution of furanoid and pyranoid tautomers in water, dimethyl sulphoxide, and pyridine. Studies on ketoses. Part 4. J Chem Soc Perkin Trans 2, 1489-1497.

Lichtenthaler, F. W., Immel, S. \& Kreis, U. (1991). Evolution of the structural representation of sucrose. Starch/Stärke 43, 121-132.

Loesche, W. J. (1986). Role of Streptococcus mutans in human dental decay. Microbiol Rev 50, 353-380.

Meadow, N. D., Fox, D. K. \& Roseman, S. (1990). The bacterial phosphoenolpyruvate:glycose phosphotransferase system. Annu Rev Biochem 59, 497-542.

Minami, T., Fujiwara, T., Ooshima, T., Nakajima, Y. \& Hamada, S. (1990). Interaction of structural isomers of sucrose in the reaction between sucrose and glucosyltransferases from mutans streptococci. Oral Microbiol Immunol 5, 189-194.

Nagao, Y., Nakada, T., Imoto, M., Shimamoto, T., Sakai, S., Tsuda, M. \& Tsuchiya, T. (1988). Purification and analysis of the structure 
of $\alpha$-galactosidase from Escherichia coli. Biochem Biophys Res Commun 151, 236-241.

Ooshima, T., Izumitani, A., Sobue, S., Okahashi, N. \& Hamada, S. (1983). Non-cariogenicity of the disaccharide palatinose in experimental dental caries of rats. Infect Immun 39, 43-49.

Ooshima, T., Izumitani, A., Minami, T., Fujiwara, T., Nakajima, Y. \& Hamada, S. (1991). Trehalulose does not induce dental caries in rats infected with mutans streptococci. Caries Res 25, 277-282.

Peltroche-Llacsahuanga, H., Hauk, C. J., Kock, R., Lampert, F., Lütticken, R. \& Haase, G. (2001). Assessment of acid production by various human oral micro-organisms when palatinose or leucrose is utilized. J Dent Res 80, 378-384.

Perna, N. T., Plunkett, G., III, Burland, V. \& 25 other authors (2001). Genome sequence of enterohaemorrhagic Escherichia coli O157: H7. Nature 409, 529-533.

Postma, P. W., Lengeler, J. W. \& Jacobson, G. R. (1993). Phosphoenolpyruvate:carbohydrate phosphotransferase systems of bacteria. Microbiol Rev 57, 543-594.

Raasch, C., Streit, W., Schanzer, J., Bibel, M., Gosslar, U. \& Liebl, W. (2000). Thermotoga maritima AglA, an extremely thermostable $\mathrm{NAD}^{+}, \mathrm{Mn}^{2+}$, and thiol-dependent $\alpha$-glucosidase. Extremophiles 4, 189-200.

Rauch, P. J. G. \& deVos, W. M. (1992). Transcriptional regulation of the Tn5276-located Lactococcus lactis sucrose operon and characterization of the $s a c A$ gene encoding sucrose-6-phosphate hydrolase. Gene 121, 55-61.

Reid, S. J., Rafudeen, M. S. \& Leat, N. G. (1999). The genes controlling sucrose utilization in Clostridium beijerinckii NCIMB 8052 constitute an operon. Microbiology 145, 1461-1472.

Robrish, S. A. \& Thompson, J. (1990). Regulation of fructose metabolism and polymer synthesis by Fusobacterium nucleatum ATCC 10953. J Bacteriol 172, 5714-5723.

Robrish, S. A., Oliver, C. \& Thompson, J. (1987). Amino aciddependent transport of sugars by Fusobacterium nucleatum ATCC 10953. J Bacteriol 169, 3891-3897.

Robrish, S. A., Oliver, C. \& Thompson, J. (1991). Sugar metabolism by fusobacteria: regulation of transport, phosphorylation, and polymer formation by Fusobacterium mortiferum ATCC 25557. Infect Immun 59, 4547-4554.

Schmid, K., Ebner, R., Altenbuchner, J., Schmitt, R. \& Lengeler, J. (1988). Plasmid-mediated sucrose metabolism in Escherichia coli K12: mapping of the $s c r$ genes of pUR400. Mol Microbiol 2, 1-8.

Slee, A. M. \& Tanzer, J. M. (1979). Phosphoenolpyruvate-dependent sucrose phosphotransferase activity in Streptococcus mutans NCTC 10449. Infect Immun 24, 821-828.

Sprenger, G. A. \& Lengeler, J. W. (1988). Analysis of sucrose catabolism in Klebsiella pneumoniae and in $\mathrm{Scr}^{+}$derivatives of Escherichia coli K12. J Gen Microbiol 134, 1635-1644.

St Martin, E. J. \& Wittenberger, C. L. (1979). Characterization of a phosphoenolpyruvate-dependent sucrose phosphotransferase system in Streptococcus mutans. Infect Immun 24, 865-868.

Sutrina, S. L., Reddy, P., Saier, M. H., Jr \& Reizer, J. (1990). The glucose permease of Bacillus subtilis is a single polypeptide chain that functions to energize the sucrose permease. J Biol Chem 265, 18581-18589.

Tangney, M., Rousse, C., Yazdanian, M. \& Mitchell, W. J. (1998). Sucrose transport and metabolism in Clostridium beijerinkii NCIMB 8052. J Appl Microbiol 84, 914-919.

Thompson, J. \& Chassy, B. M. (1981). Uptake and metabolism of sucrose by Streptococcus lactis. J Bacteriol 147, 543-551.

Thompson, J., Nguyen, N. Y., Sackett, D. L. \& Donkersloot, J. A. (1991). Transposon-encoded sucrose metabolism in Lactococcus lactis. Purification of sucrose-6-phosphate hydrolase and genetic linkage to $N^{5}$-(L-1-carboxyethyl)-L-ornithine synthase in strain K1. J Biol Chem 266, 14573-14579.

Thompson, J., Nguyen, N. Y. \& Robrish, S. A. (1992). Sucrose fermentation by Fusobacterium mortiferum ATCC 25557: transport, catabolism, and products. J Bacteriol 174, 3227-3235.

Thompson, J., Gentry-Weeks, C. R., Nguyen, N. Y., Folk, J. E. \& Robrish, S. A. (1995). Purification from Fusobacterium mortiferum of a 6-phosphoryl-O- $\alpha$-D-glucopyranosyl:6-phosphoglucohydrolase that hydrolyzes maltose 6-phosphate and related phospho- $\alpha$-D-glucosides. J Bacteriol 177, 2505-2512.

Thompson, J., Pikis, A., Ruvinov, S. B., Henrissat, B., Yamamoto, H. \& Sekiguchi, J. (1998). The gene glvA of Bacillus subtilis 168 encodes a metal-requiring, $\mathrm{NAD}(\mathrm{H})$-dependent 6-phospho- $\alpha$ glucosidase. Assignment to family 4 of the glycosylhydrolase superfamily. J Biol Chem 273, 27347-27356.

Thompson, J., Ruvinov, S. B., Freedberg, D. I. \& Hall, B. G. (1999). Cellobiose-6-phosphate hydrolase (CelF) of Escherichia coli: characterization and assignment to the unusual family 4 of glycosylhydrolases. J Bacteriol 181, 7339-7345.

Thompson, J., Robrish, S. A., Pikis, A., Brust, A. \& Lichtenthaler, F. W. (2001a). Phosphorylation and metabolism of sucrose and its five linkage-isomeric $\alpha$-D-glucosyl-D-fructoses by Klebsiella pneumoniae. Carbohydr Res 331, 149-161.

Thompson, J., Robrish, S. A., Immel, S., Lichtenthaler, F. W., Hall, B. G. \& Pikis, A. (2001b). Metabolism of sucrose and its five linkage-isomeric $\alpha$-D-glucosyl-D-fructoses by Klebsiella pneumoniae: participation and properties of sucrose-6-phosphate hydrolase and phospho- $\alpha$-glucosidase. J Biol Chem 276, 37415-37425

Titgemeyer, F., Jahreis, K., Ebner, R. \& Lengeler, J. W. (1996). Molecular analysis of the scrA and scrB genes from Klebsiella pneumoniae and plasmid pUR400, which encode the sucrose transport protein enzyme $\mathrm{II}^{\mathrm{ser}}$ of the phosphotransferase system and a sucrose-6-phosphate invertase. Mol Gen Genet 250, 197-206.

Van Houte, J. (1994). Role of microorganisms in caries etiology. $J$ Dent Res 73, 672-681.

Ziesenitz, S. C., Siebert, G. \& Imfeld, T. (1989). Cariological assessment of leucrose [D-glucopyranosyl- $\alpha(1-5)$-D-fructopyranose] as a sugar substitute. Caries Res 23, 351-357.

Received 3 September 2001; revised 5 November 2001; accepted 8 November 2001. 